九州大学学術情報リポジトリ

Kyushu University Institutional Repository

Potamoid Crabs of the Ryukyu Islands? with Desrciptions of Five New Species (Crustacea, Decapoda, Potamoidea)

Minei, Hisakatsu

Zoological Laboratory, Faculty of Agriculture, Kyushu University

https://doi.org/10.5109/22832

出版情報：九州大学大学院農学研究院紀要. 17 (2)，pp. 203-226，1973-03. Kyushu University バージョン：

権利関係 : 
J. Fac. Agr., Kyushu Univ., 17, 203-226 (1973)

\title{
Potamoid Crabs of the Ryukyu Islands? with Desrciptions of Five New Species (Crustacea, Decapoda, Potamoidea)
}

\author{
Hisakatsu Minei \\ Zoological Laboratory, Faculty of Agriculture, \\ Kyushu University, Fukuoka \\ (Received O ctober 12, 1972)
}

\begin{abstract}
The Potamoidea of the Ryukyu Islands are reported to include 12 species divided in three genera. Of these five are newly described: Geothelphusa aramotoi sp. nov., Candidiopotamon amamense sp. nov., Candidiopotamon okinawense sp. nov., Candidiopotamon kumejimense sp. nov. and Nanhaipotamon yaeyamense sp. nov. Newly recorded from the area are two species which have been known from Taiwan only : Geothelphusa candidiensis Bott and Geothelphusa miyazakii (Miyake \& Chiu).
\end{abstract}

The fresh-water crab Potamoidea of the Ryukyu Islands have been studied by many workers such as Stimpson (1858, 1907), A. Milne Edwards (1869), de Man (1892), Ortmann (1897), Rathbun (1898, 1905), Parisi (1916), Koba (1936), Balss (1937), Sakai (1939), Pretzmann (1963), Minei (1963, 1968), Miyake (1963), Miyake \& Minei (1965) and Bott $(1967,1968,1970)$. And up to the present five species in two genera have been known to occur in this area.

From the concerned area a considerable number of specimens have been collected, which are preserved in the Zoologcal Laboratory, Kyushu University, and extensive collection has also been made by the author himself. On examination of these specimens numbering about 900, twelve species in three genera of the Potamoidea are recognized to occur in the Ryukyu Islands. Of these two are newly recorded, and five are described as new to science.

All the type specimens are preserved in the Zoological Laboratory, Kyushu University, Fukuoka.

Geothelphusa obtusipes Stimpson, 1858

(Figs. 1; 4 A, B)

Jap. name : Ryukyu-sawagani

Geothel phusa obtusipes Stimpson 1858, p. 101 ; 1907. p. 113; de Man 1892, p. 290.

Thelphusa obtusipes : A. Milne Edwards 1869, p. 175, pl. 10, figs. 1, la \& lb.

Potamon (G eothel phusa) obtusipes : Ortmann 1897, p. 310.

Material examined. Amami-ohshima. Urakami-gawa, Naze city, 2 § 5 우, young crabs-laden 1 f , ZLKUm. 1038, Oct. 15, 1968, H. Minei leg. ; Ara-kawa (Kasuga), young crabs-laden 1 우, m. 1043, Oct. 1, 1968, H. Minei leg. ; Manatsu-gawa (branch of Ara-kawa), 17 ㅈ, 26 우, m. 1036, Oct. 1, 1968, H. Minei leg. ; Asato- 
gawa (Asato), 8 §, 8우, young crabs-laden 1 우, 'ZLKU 9676, Aug. 8, 1955, K. Koba leg. ; 8 ð, 6 우, m. 1046, Oct. 4, 1968, H. Minei leg.

Kawauchi-gawa (Kawauchi), Sumiyo-son, 5 ð, 2 우, m. 1044, Oct. 13, 1968, H. Minei leg. ; Kawauchi-gawa (Surugachi), 6 ð, 8 ஓ , 9711, Aug. 9, 1954, K. Koba leg. ; Sumiyo-gawa (Ueda), 5 a, 4 ㅇ, m. 1028, Aug. 9, 1966, M. Takeda leg. ; 2 ๙ 3 우, m. 1056, Mar. 19, 1970, H. Minei leg. ; Yakkachi-gawa (Shinmura), 9 ð, 9 우, m. 1039, Oct. 17, 1968, H. Minei leg. ; 19 ð. 25 우, m. 1063, Mar. 18, 1970, H. Minei leg. leg.

Fukumoto, Yamato-son, 2 ð, 7 우, 10923, July 31, 1964, K. Koba \& K. Baba

Yuwan, Uken-son, 10 a, 11 우, m. 1077, Mar. 20, 1970, H. Minei leg.

Tokuno-shima. Tete, Tokunoshima-cho, 13 ๙ , 17 우, m. 1073, Mar. 29, 1970, H. Minei leg. ; Ketokina, 2 §, 2 우, m. 1017, Mar. 28, 1970, H. Minei leg. ; Kametokugawa (Kametoku), 1 ð, 9703, Aug. 7, 1955, K. Koba leg.

Masena-gawa (Minata), Amagi-cho, 10 6, 16 우, m. 1045, Oct. 8, 1968, H. Minei leg. ; Akirigami-gawa (Mikyo), 2 ㅈ, 2 우, young crabs-laden 1 우, 9697, Aug. 1, 1955, K. Koba leg.

Shikaura-gawa (Bane), Isen-cho, 1 ð, 2 ㅇ, m. 1046, Oct. 10, 1968, H. Minei leg. ; 3 ऽ, 3 우, m. 1068, Mar. 26, 1970, H. Minei leg.

Material illustrated. Dorsal view of male and first pleopod ; Masena-gawa, 1 ๙ , m. 1045, Oct. 8, 1968, H. Minei leg.

Remarks, Morphologically this species is characterized by the following.

1. The species is usually of small size, its biological minimum is about 20 $\mathrm{mm}$ in carapace breadth.

2. The carapace and the cheliped bear tubercles and short striae. The propodus of the 2 nd ambulatory leg is 2.0 times as long as broad ; the dactylus is stout.

3. The merus of the third maxilliped is 0.7 times as long as broad.

4. The penultimate segment of the first pleopod is straight. The ultimate segment is slightly curved outwards, and both the lateral sides is straight near the tip. The synovial membrane is 3.0 times as long as broad.

This species is closely related to Geothelphusa sakamotoana, from which it may be distinguished by the above-mentioned characters. From G. dehaani, which is also very allied, it differs in having the tubercles on the dorsal surface of the carapace, in the proportion of the propodus of the legs, the gape of the fingers of the large chela and the shape of the first pleopod.

Measurements. See Table 1.

Distribution. Amami-ohshima (Stimpson 1858, 1907 ; A. Milne Edwards 1869 ; de Man 1892; Ortmann 1897), Tokuno-shima (new record).

Geothelphusa sakamotoana (Rathbun, 1905)

(Figs. 2; 4 E, F)

Jap. name : Sakamoto-sawagani

Potamon (Geothelphusa) sakamotoanus Rathbun 1905, p. 206, pl. 18, fig. 6 ; Minei 1963, p. 
Table 1. Measurements of four species (in $\mathrm{mm}$ ).

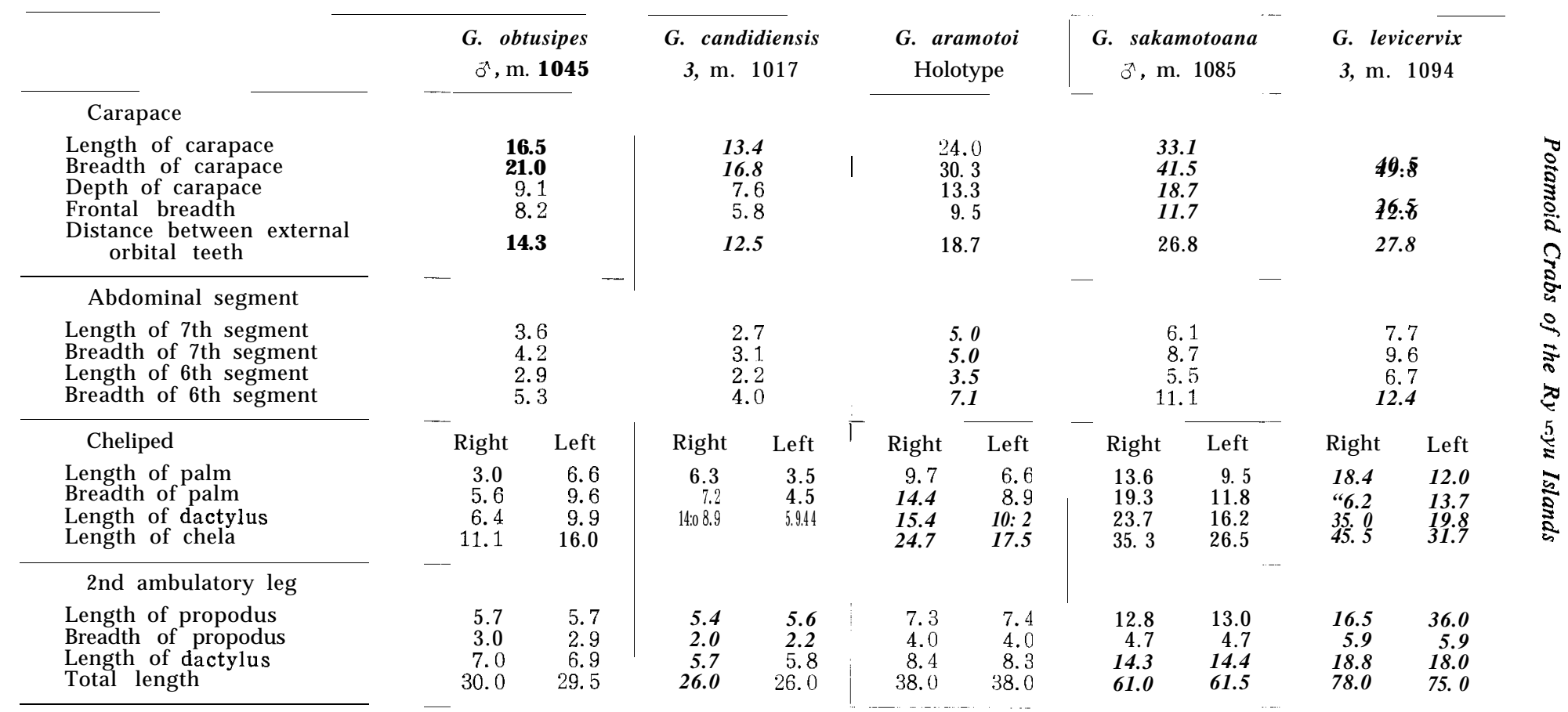




\section{5, fig. 2.}

Geothelphusa dehaani sakamotoana : Bott 1967, p. 213, fig. 13.

G eothelphusa obtusipes: Bott 1970, p. 155, pl. 40, fig. 59 ; pl. 53, fig. 62 .

Material examined. Amami-ohshima. Ohi-gawa, Kasari-cho, $1 \curvearrowright, 1$ ㅇ, ZLKU 9670, July 20, 1955, K. Koba leg. ; Yani-gawa (Nabegoro), 7 ఠ, 3 우, ZLKUm. 1080, Aug. 8, 1966, M. Takeda leg. ; $31 \precsim, 26$ ㅇ, young crabs-laden 7 \%, m. 1048, Oct.

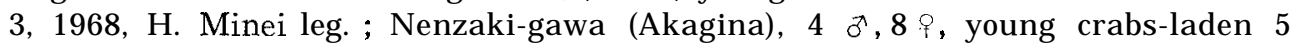
\&, m. 1050, Oct. 2, 1968, H. Minei leg. ; Maeda-gawa, 1 ð, m. 1051, Oct. 1, 1968, H. Minei leg.

Ohbi-gawa (Kawauchi), Tatsugo-son, 3 ㄱ, 5 우, young crabs-laden 1 우, m. 1055, Oct. 4, 1968, H. Minei leg.

Urakami-gawa, Naze city, 1 ð, 1 우, young crabs-laden 1 우, m. 1051, Oct. 19 , 1968, H. Minei leg. ; Manatsu-gawa (branch of Ara-kawa), $11 \hat{\jmath}, 4$ 우, young crabsladen 1 ㅇ, m. 1054, Oct. 1, 1968, H. Minei leg. ; Asato-gawa (Asato), 1 ð , 9675, Aug. 8, 1955, K. Koba leg. ; 1 a, m. 1047, Oct. 14, 1968, H. Minei leg.

Iwabata-yama, Sumiyo-son, 1 đ , 9669, Aug. 10, 1954, K. Koba leg. ; Kawauchigawa (Kawauchi), 1 ㅇ, 9694, Aug. 10, 1954, K. Koba leg. ; 8 ๙ , 4 우, young crabsladen 1 ㅇ, m. 1052, Oct. 13, 1968, H. Minei leg. ; Sumiyo-gawa (Ueda), 2 ๙, 2 ㅇ, m. 1078, Aug. 9, 1966, M. Takeda leg. ; Yakkachi-gawa (Shinmura), 6 ð, 6 우, young crabs-laden 2 우, m. 1049, Oct. 17, 1968, H. Minei leg. ; 7 ð, 6 ९, m. 1064, Mar. 18, 1970, H. Minei leg.

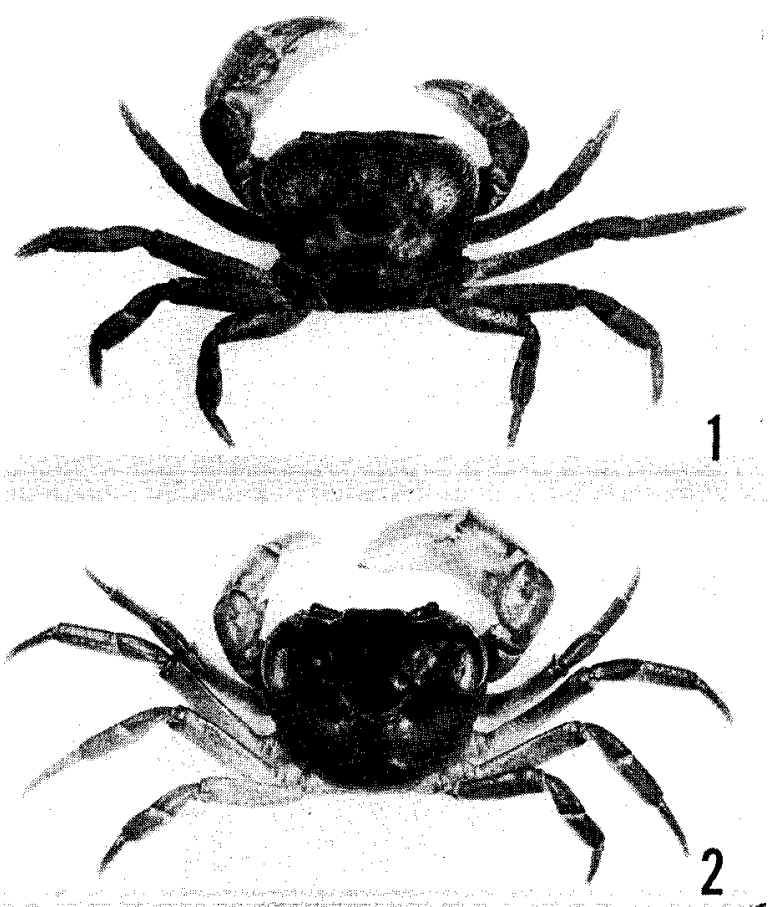

Figs. 1-2. 1 : G eothel phusa obtusipes Stimpson. 2 : G eothelphusa sakamotoana (Rathbun). 
Fukumoto, Yamato-son, 1 a, 3 ㅇ, 10923, July 29, 1964, K. Koba \& K. Baba leg.

Yuwan-dake, Uken-son, 1 우, 10921, July 30, 1964, K. Koba \& K. Baba leg. ; Yuwan, 1 ð, 1 ๆ, m. 1076, Mar. 20, 1970, H. Minei leg.

Tokuno-shima. Tete, Tokunoshima-cho 1 ๙, m. 1075, Mar. 29, 1970, H. Minei.; Ketokina, 2 §, 2 우, m. 1072, Mar. 28, 1970, H. Minei leg. ; Inokawa, 15 ๙, 6 우, m. 1066, Mar. 27, 1970, H. Minei leg. ; Kametoku-gawa (Kametoku), 4 ð, 1 우, m. 1081, Oct. 11, 1968, H. Minei leg.

Masena-gawa (Kaneku), Amagi-cho, 29 ð̋, 22 우, young crabs-laden 4 우, m. 1083, Oct. 8, 1968, H. Minei leg. ; Akirigami-gawa (Nishiagina), $8 \precsim, 6$ ㅇ, young crabs-laden 1 ९, m. 1087, Oct. 9, 1968, H. Minei leg.

Shikaura-gawa (Bane), Isen-cho, $15 \curvearrowright, 15$, young crabs-laden 2 \%, m. 1085, Oct. 10, 1968, H. Minei leg. ; 4 §, m. 1069, Mar. 26, 1970, H. Minei leg.

Okinawa-jima. Fuku-gawa (branch of Aha-gawa), Kunigami-son, $2 \approx, 3$ 오,

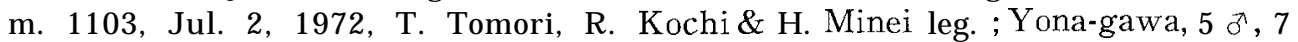
ㅇ, m. 1015, Feb. 28, 1962, K. Kawashima leg. ; 8 ð, 7 ९, m. 1013, Jul. 10, 1962, H. Minei leg. ; Yonaha-dake, 1 ९, 9796, May 21, 1961, H. Minei leg.

Kizoka, Ohgimi-son, 1 ๙ , 1 우, 9797, May 20, 1961, H. Minei leg.

Umohara-gawa, Nago city, 2 a, 1 우, m. 1009, Feb. 25, 1962, K. Kawashima leg. ; Genga-gawa, $2 \vec{\jmath}$, m. 1012, Feb. 25, 1962, K. Kawashima leg. ; Asahi-gawa, $1 \jmath^{\star}, 1$ 우, m. 1100, Jun. 27, 1972, Y. Nakasone \& H. Minei leg. ; Kushibaru, $3 \partial^{\lambda}$, m. 1011, Feb. 25, 1962, K. Kawashima leg.

Koechi-gawa, Nakijin-son, 10 ð, 10 ㅇ, m. 1101, Jul. 1, 1972, R. Kochi\&H. Minei leg.

Izumi, Motobu-cho, 1 a, 9668, Aug. 6, 1955, K. Koba leg. ;1 $\overbrace{}^{\Uparrow}, 1$ ㅇ, 9800, May 23, 1961, H. Minei leg. ; $1 \precsim, 4$ ㅇ, m. 1010, Feb. 25, 1962, K. Kawashima leg. ; Manna-gawa, $2 \widehat{\jmath}, 2$ ㅇ, m. 1102, Jun. 28, 1972, Y. Nakasone \& H. Minei leg.

Shuri, Naha city, 23 §, 14 우, 3 ovig. 우, 10990, Jun. 17, 1962, S. Miyake, T. A. Uchida \& H. Minei leg.

Shikiya, Chinen-son, 2 §, 2 우, 1 ovig. 우, m. 1099, Jun. 25, 1972, H. Minei leg.

Fusato, Tamagusuku-son, 3 ㄱ, 3 우, 1 ovig. 우, m. 1098, Jun. 23, 1972, H. Minei leg.

Mukui-gawa (Yoza), Itoman city 2 え, 3 ․, m. 1097, Jun. 23, 1972, H. Minei leg.

Material illustrated. Dorsal view of male and first pleopod; Shikaura-gawa, 1 a, m. 1085, Oct. 10, 1968, H. Minei leg.

Remarks. The characteristics of this species are found in the following respects.

1. This species is of median size, its biological minimum is about $28 \mathrm{~mm}$ in carapace breadth.

2. The carapace and the cheliped bear faintly crenulate. In the 2nd ambulatory leg the propodus is 2.7 times as long as broad; the dactylus is slender.

3. The merus of the third maxilliped is 0.9 times as long as broad. 
4. The first pleopod is slightly curved outwards; the tip of the ultimate segment bears a papilla. The synovial membrane is 4.0 times as long as broad.

This species is allied to Geothelphusa levicervix (Rathbun) previously recorded from the Okinawa-jima, from which it is distinguished by the size of the adult, the convexity of the carapace, the gape of the fingers of the large chela and the shape of the first pleopod. According to Bott (1970), this species has been considered as a synonym of Geothelphusa obtusipes, but it is thought that his specimen should be referred to G. sakamotoana. Bott's specimen might be a young of this species.

Measurements. See Table 1.

Distribution. Amami-ohshima (new record), Tokuno-shima (new record), Okinawa-jima (Rathbun 1905 ; Minei 1963 ; Bott 1967, 1970).

\section{Geothelphusa aramotoi sp. nov.}

(Figs. $3 ; 4$ G, H)

New Jap. name : Aramoto-sawagani

? Potamon (Geothel phusa) obtusipes : Rathbun 1905, p. 207, pl. 38, fig. 8 (in part) ; Parisi 1916, p. 164 (in part).

? Geotelphusa obtusipes : Koba 1936, p. 169, pl, 2. fig. 2.

Material examined. Holotype. Taminato, Ohgimi-son, Okinawa-jima,, ZLKUm. 1106, Jan. 29, 1972, Y. Aramoto leg.

Paratypes. Okinawa-jima. Taminato, Ohgimi-son, 5 ð, 5 `, m. 1096, Jul. 2, 1972 , Y. Nakasone \& H. Minei leg.

Genga-gawa, Nago city, 1 a, 1 , m. 1111, Feb. 25, 1962, K. Kawashima leg. ; 3 ðð, 2 우, m. 1095, Jun. 29, 1972, Y. Nakasone \& H. Minei leg. ; Umohara-gawa, $1 \precsim, 1$ 우, m. 1112, Feb. 25, 1962, K. Kawashima leg.

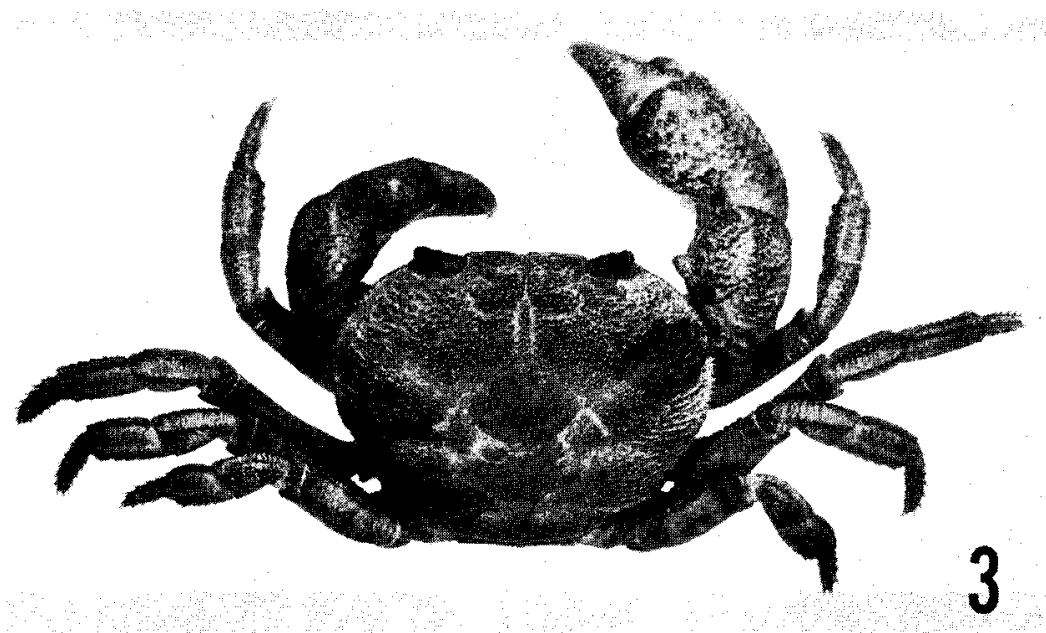

Pig. 3. Geothel phusa aramotoi sp. nov. 
Izumi, Motobu-cho, 3 ऽ,2 , 9802, May 23, 1961, H. Minei leg.

Material illustrated. Holotype.

Diagnosis. Carapace flat, with crenulate striae, tubercles and coarsely pitted granules dorsally. First pleopod straight, synovial membrane 5.6 times as long as broad. Second ambulatory leg 1.3 times the breadth of carapace; propodus 1.8 times as long as broad; dactylus stout.

Description of holotype. The length of the carapace is 0.79 times its greatest breadth and the depth is slightly more than half the length. The dorsal surface is practically flat exclusive of the frontal and orbital regions ; it is closely covered with tuberclesand coarsely pitted granules. The postfrontal, postorbital and epibranchial regions are covered with many tubercles and crenulate striae. The anterolateral margin of the carapace bears distinctly crenulate striae. The posterolateral margin and the subbranchial region have likewise many crenulate striae. The frontal region bears a group of large and very conspicuous tubercles and its breadth is 0.31 times as broad as the carapace and about half the distance between the external orbital teeth. The exopod of the third maxilliped reaches the proximal twofifths of the merus; the merus is 0.76 times as long as broad.

The 7th abdominal segment is as long as broad, and 3.4 times the length of the 6th. The 6th segment is half as long as broad. The first pleopod is straight ; the penultimate segment is 5.0 times the length of the ultimate; the ultimate segment is straight; the synovial membrane is 5.6 times as long as broad.

In the chelipeds the right is strongly longer than the left. The carpus of the right bears crenulate striae and one large spine and two blunt spinules on the inner portion. The palm bears crenulate striae on the dorsal margin and is smooth on the ventral margin. The fingers are moderately gaped when closed, with a series of 5 to 7 small teeth on each cutting edge. The palm is 1.8 times as long as broad, 0.63 times the length of the dactylus and 0.39 times the length of the chela. The carpus and palm of the left cheliped bear tubercles and crenulate striae. The ambulatory legs are stout, with short striae and coarsely pitted granules. The propodus and the dactylus bear short hairs. The 2nd ambulatory leg is 1.3 times the breadth of the carapace ; the propodus is 1.8 times as long as broad ; the dactylus is stout. The propodus bears one row of spinules dorsally and two rows of spinules ventrally. The dactylus bears each two rows of spinules dorsally and ventrally; ten spinules arranged in two rows are present ventrally.

Remarks. This species is very allied to Geothelphusa obtusipes (Stimpson) in general appearance, but it differs in the following. In G. obtusipes the carapace bears several tubercles and short striae. The propodus of the 2 nd ambulatory leg is 2.0 times as long as broad. The ultimate segment is slightly curved outwards; the synovial membrane is 3.0 times as long as broad. In G. aramotoi the carapace bears many tubercles and coarsely pitted granules. The propodus of the 2nd ambulatory leg is 1.8 times as long as broad. The ultimate segment is straight; the synovial membrane is 5.6 times as long as broad.

Measurements. See Table 1.

Distribution. Okinawa-jima.

Geothelphusa tenuimana (Miyake \& Minei, 1965)

(Figs. 5; 9 A, B)

Jap. name : Himeyuri-sawagani

Potamon (Geothelphusa) tenuimanus Miyake \& Minei 1965, p. 377, figs. 1-4, pl. 21. 



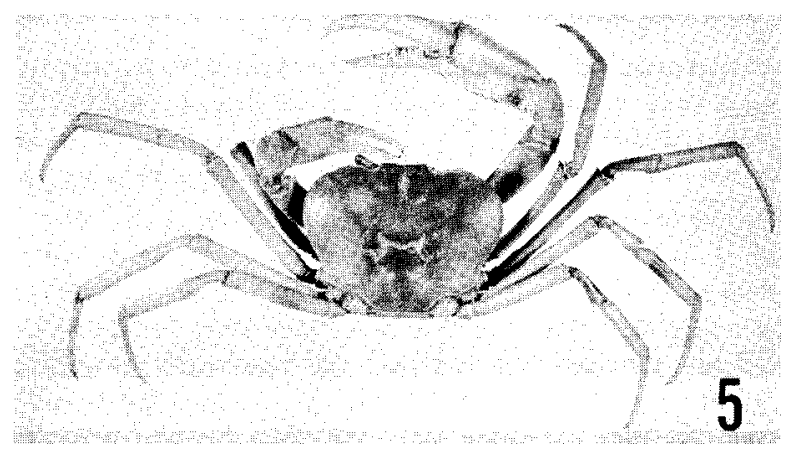

Fig. 5. Geothelphusa tenuimana (Miyake \& Minei).

of Geothelphusa levicervix (Rathbun). However, I am of opinion that they are distinct each other for the following regards. In G. levicervix the subbranchial region is slightly distensible. The depth of the carapace is 0.7 times the length of the carapace. The propodus of the 2nd ambulatory leg is 2.8 times as long as broad. The penultimate segment of the first pleopod is slightly curved inwards ; the ultimate segment is strongly curved outwards ; the synovial membrane is 4.0 times as long as broad. In G. tenuimana the subbranchial region is strongly distensible. The depth of the carapace is 0.6 times the length of the carapace. The propodus of the 2 nd ambulatory leg is 5.0 times as long as broad. The penultimate segment of the first pleopod is moderately curved inwards; the ultimate segment is slightly curved outwards; the synovial membrane is 5.0 times as long as broad.

Distribution. Okinawa-jima.

Geothelphusa levicervix (Rathbun, 1898)

(Figs. 6; 9 C, D)

Jap. name : Oh-sawagani

Potamon (Geothelphusa) levicervix Rathbun 1898, p. 28, pl. 2, figs. 5-8 ; 1905, p. 223, pl. 18 , fig. 12 .

Geothelphusa levicervix : Bott 1970, p. 155, pl. 58, figs. 93, 94.

Geothelphusa dehaani : Stimpson 1907, p. 112, pl. 17, fig. 2.

Material examined. Okinawa-jima. Meiji-yama, Nago city, 1 우, 1 ovig. 우, ZLKU 9666, Aug. 5, 1956, K. Koba leg.

Fusato (Yambaru-yama), Tamagusuku-son, 2 6, 1 予, 10987, Jun. 26, 1962, H. Minei leg. ; 2 ð, 2 우, m. 1094, Jun. 25, 1972, H. Minei leg.

Material illustrated. Dorsal view of male and first pleopod ; Fusato, §^, m. 1094, Jun. 25, 1972, H. Minei leg.

Description. The carapace is smooth, and strongly convex in a fore and aft direction; the depth is 0.7 times the length of the carapace. The frontal region is 0.25 times the breadth of the carapace, and 0.45 times the distance between the external orbital teeth. The an- 
terolateral margin of the carapace is smooth or obsolete. The exopod of the third maxilliped reaches the proximal third of the merus; the merus is slightly shorter than broad.

In the male the 7th abdominal segment is 0.8 times as long as broad and longer than the 6 th. The 6 th segment is half as long as broad. The penultmate segment of the first pleopod is slightly curved inwards, and 6.0 times the length of the ultimate ; the ultimate segment is strongly curved outwards ; the synovial membrane is 4.0 times as long as broad.

The chelipeds are unequal in males, but subequal in females. The carpus of the large cheliped bears indistinct striae and one large spine on the innner portion. The fingers have a large gape when closed. The palm is smooth ; it is 0.7 times as long as broad, and about half the length of the dactylus. The dactylus is 0.9 times the length of the chela. The small cheliped is similar in shape to those of the females ; the fingers are not gaping when closed. The ambulatory legs are stout. The 2 nd ambulatory leg is 1.6 times the breadth of the carapace; the propodus is 2.8 times as long as broad.

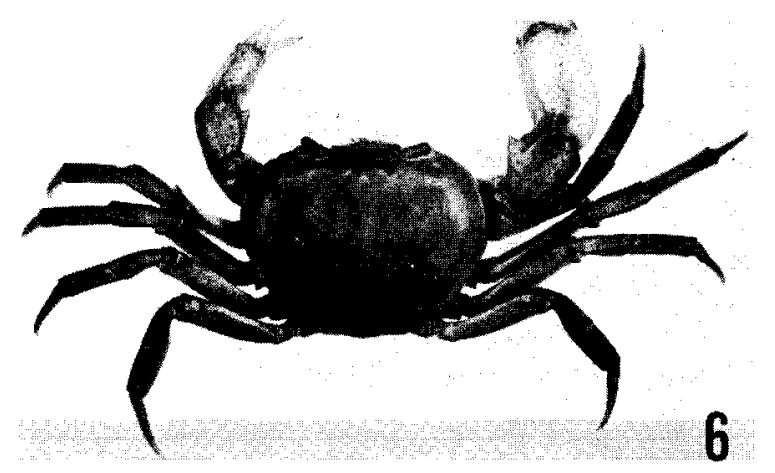

Fig. 6. G eothelphusa levicervix (Rathbun).

Remarks. The fresh-water crab collected from the Amakirrima Islands (=Kerama Islands) was referred to Geothelphusa dehaani (White) by Stimpson (1907). Judging from the description of the adult and the figure in the plate given by Stimpson, it however seems to be identical with Geothel phusa levicervix (Rathbun).

Measurements. See Table 1 .

Distribution. Okinawa-jima (Rathbun 1898, 1905 ; Bott 1970), Kerama Islands (Stimpson 1907).

Geothelphusa candidiensis Bott, 1967

(Figs. 7; $9 \mathrm{E}, \mathrm{F}$ )

New Jap. name : Taiwan-sawagani

G eothel phusa dehaani candidiensis Bott 1967, p. 212, pl. 10, fig. $12 ; 1970$, p. 157, pl. 40, figs. 62,63 ; pl. 53, fig. 64 .

Potamon (Geothelphusa) obtusipes : Miyake 1963, p. 66, fig. 4.

Material examined. Ishigaki-jima. Maezato, Ishigaki city, 5 ๙, 3 우, ZLKU m. 
1018, Mar. 9, 1962, K. Kawashima leg. ; 5 §, 4 우, m. 1016, Oct. 28, 1962, S. Kudaka leg. ; Pensan-gara, 19 ð, 18 . , m. 1019, May 19, 1963, S. Kudaka leg. ;Karazaki, 5 §, 6 우, m. 1022, May 20, 1963, S. Kudaka leg. ; Sakie, Yarabe-dake, 3 우, m. 1021, Feb. 22, 1964, S. Kudaka leg. ; Banna-dake, 1 ð, 8849, Jun. 24, 1934, H. Ohshima leg. ; Kira-dake, $6{ }^{\star}, 4$ 우 , m. 1108, May 27, 1968, Y. Hashiguchi leg. ; Kindake, 8 ๙, 7 ㅇ, m. 1109, Jul. 24, 1968, Y. Hashiguchi leg.

Iriomote-jima. Nakama-gawa, Taketomi-cho, 2 ð, 2 웅. m. 1110, May 7, 1962, K. Kawashima leg.

Material illustrated. Dorsal view of male and first pleopod ; Maezato, $\widehat{0}, \mathrm{~m}$. 1016, Oct. 28, 1962, S. Kudaka leg.

Description. The length of the carapace is 0.8 times its greatest breadth and the depth is slightly more than half the length. The dorsal surface behind the postfrontal region is slightly convex in a fore and aft direction. The postfrontal region is covered with indistinct striae. The postorbital and epibranchial regions bear finely crenulate striae. The anterolateral margin of the carapace bears finely crenulate striae and the posterolateral margin and the subbranchial region have distinctly many granulated striae and short hairs. The subhepatic and the pterygostomian regions are smooth. The frontal region bears obscure tubercles, and is 0.35 times as broad as the carapace; it is 0.46 times the distance between the external orbital teeth. The orbital margin is smooth but indistinctly crenulate on the ventral. The exopod of the third maxilliped reaches the proximal third of the merus; the

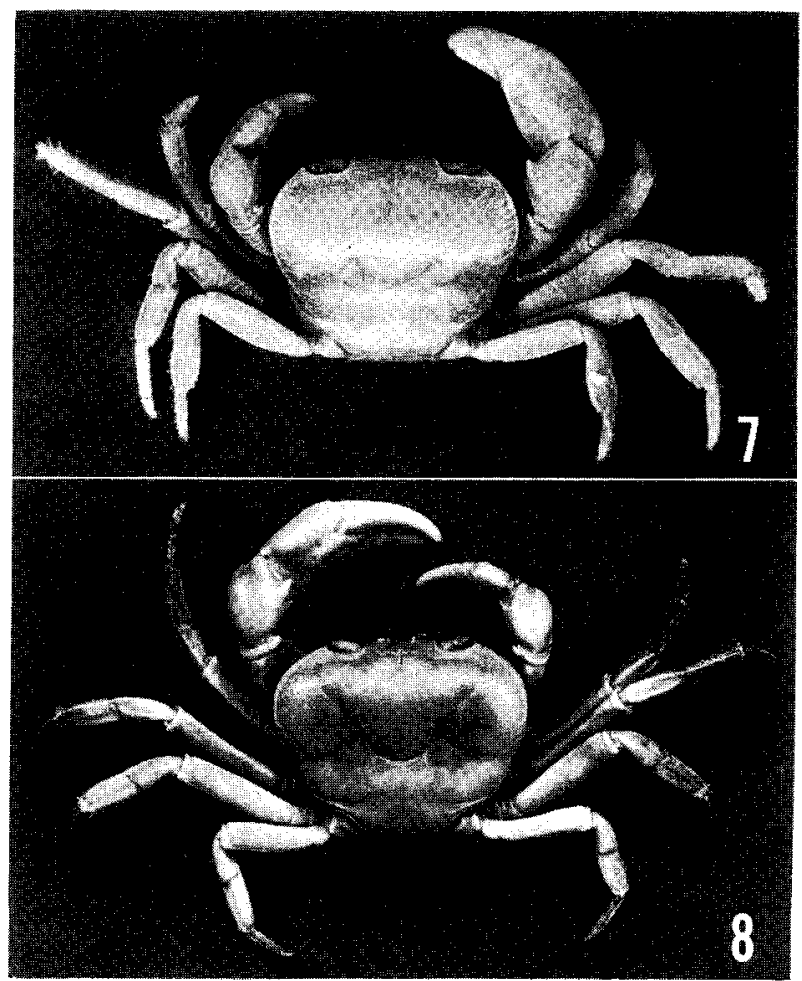

Figs. 7-8. 7: Geothelphusa candidiensis Bott. 8: Geothelphusa miyazakii (Miyake \& Chiu). 
merus is about one-third as long as broad.

In the male the 7 th abdominal segment is 0.87 times as long as broad and 1.2 times the length of the 6 th. The 6 th segment is slightly more than half as long as broad. In the first pleopod the ultimate segment is slightly curved inwards; the penultimate segment is 5.2 times the length of the ultimate; the synovial membrane is 3.7 times as long as broad.

The chelipeds are unequal in males, but subequal in females. The carpus of the large cheliped bears indistinct striae, armed with one large spine and one spinule internally. The palm is smooth. The fingers bear a series of 8 to 10 blunt small teeth and have a gape when the fingers are closed. The palm is 0.88 times as long as broad, 0.71 times the length of the dactylus and 0.45 times the length of the chela. The palm and the carpus of the small cheliped bear crenulate and short striae. The fingers are not gaping when closed, with a series of 10 to 12 small teeth on each of the cutting edges. The ambulatory legs are slender, and bear short hairs on the propodus and the dactylus. The 2 nd ambulatory leg is 1.5 times the breadth of the carapace ; the propodus is 2.5 times as long as broad, and bears one row of spinules dorsally and two rows of spinules ventrally. The dactylus bears each two rows of spinules dorsally and ventrally ; fourteen spinules arranged in two rows are present ventrally.

Remarks. According to Bott $(1967,1970)$, this species has been considered as a subspecies of Geothelphusa dehaani (White), from which it is distinguished by the crenulate striae of the carapace and the shape of the first pleopod. From these distinct characters, it is thought that this should be known as a distinct species.

Measurements. See Table 1.

Distribution. Ishigaki-jima (Miyake 1963), Iriomote-jima (Miyake 1963), Taiwan (Bott 1967, 1970).

Geothelphusa miyazakii (Miyake \& Chiu, 1965)

(Figs. 8; $9 \mathrm{G}, \mathrm{H}$ )

Jap. name : Miyazaki-sawagani

Potamon (Geothelphusa) miyazakii Miyake \& Chiu 1963, p. 595, pls. 13, 14.

Material examined. Ishigaki-jima. Omoto-dake, Ishigaki city, 2 ð, 2 \&,ZLKUm. 1092, Jul. 31, 1968, Y. Hashiguchi leg.

Iriomote-jima. Urauchi-gawa, Taketomi-cho, 5 ๙ึ,2 ๆ, m. 1117 May 2, 1971, S. Shokita leg.

Material illustrated. Dorsal view of male and first pleopod ;Omoto-dake, $\diamond^{\star}$, m. 1092, Jul. 31, 1968, Y. Hashiguchi leg.

Measurements. See Table 2.

Distribution. Ishigaki-jima (new rercod), Iriomote-jima (new record), Taiwan (Miyake \& Chiu 1965).

Candidiopotamon amamense sp. nov.

$$
\text { (Figs. 10, 11; } 15 \text { A, B) }
$$

New Jap. name : Amami-minami-sawagani

Material examined. Holotype. Akirigami-gawa (Ishikiridome), Amagi-cho, 


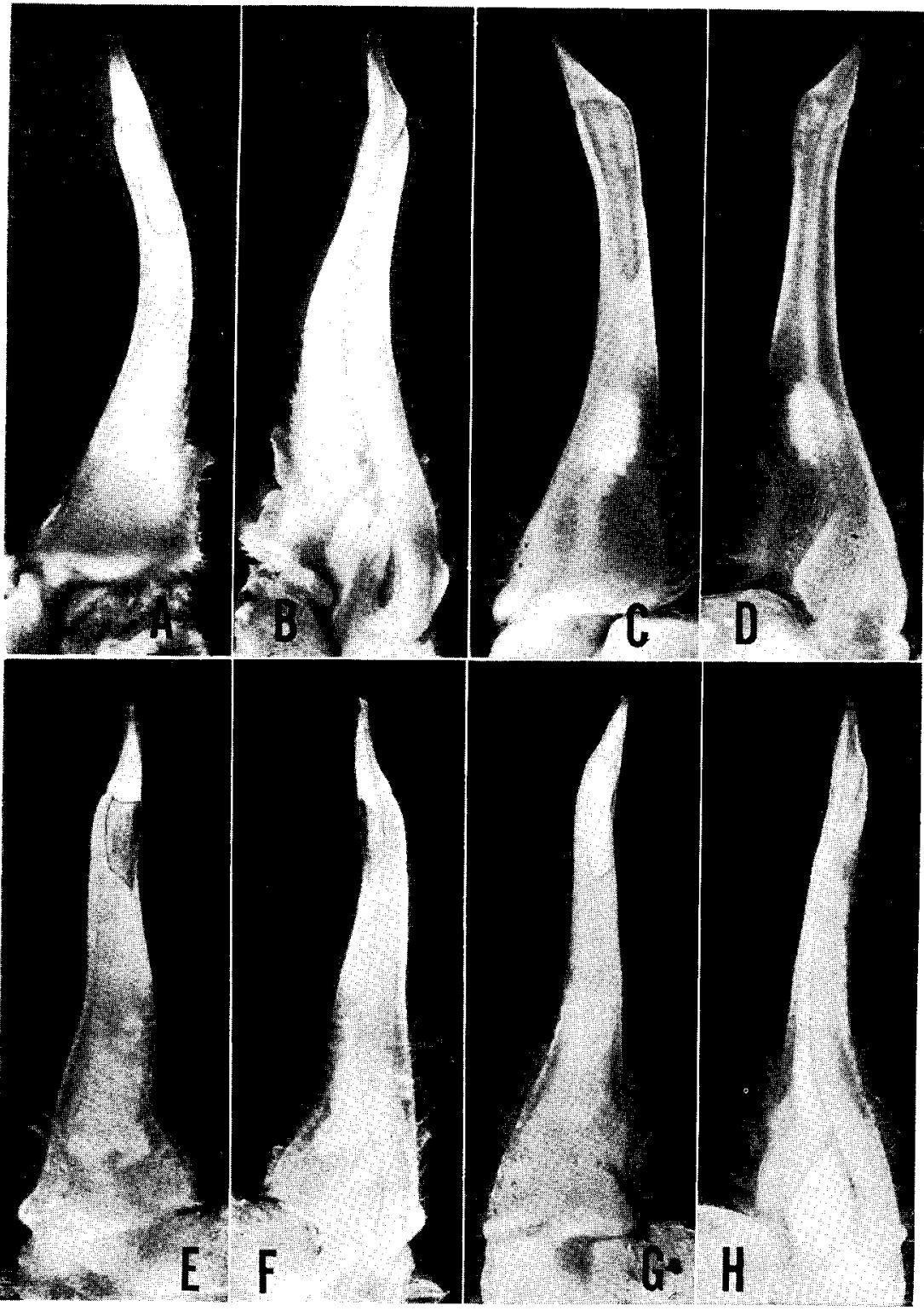

Fig. 9. Left first pteopods of four species. A, B: Geothelphusa tenuimana. C, D : Geothelphusa levicervix. E, F : Geothelphusa candidiensis. G, H:Geothelphusa miyarakii.

Tokuno-shima, Ohshima-gun, Kagoshima Pref., ð,ZLKUm. 1086, Oct. 9, 1968, H. Minei leg.

Paratypes. A mami-ohshima. Sani-gawa, Kasari-cho, 1 ð, 1 우, ZLKU 9672, July 20, 1955, K. Koba leg. ; Yani-gawa, 4 ð, m. 1030, Oct. 3, 1968, H. Minei leg Ohbi-gawa (Ohgachi), Tatsugo-son, $7 \AA$, 3 우, m. 1031, Oct. 1, 1968, H. Minei 
leg.

Urakami-gawa, Naze city, 9 ॐ, 3 ㅇ, young crabs-laden 3 भै, m. 1032, Oct. 15, 1968, H. Minei leg. ; Manatsu-gawa (branch of Ara-kawa), $7 \hat{\jmath}, 3$ q, m. 1005, Aug. 9, 1966, M. Takeda leg. ; 5 ð, 8 우, m. 1034, Oct. 14, 1968, H. Minei leg.

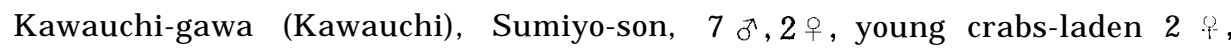
m. 1035, Oct. 13, 1968, H. Minei leg. ; Kawauchi-gawa (Surugachi), 1 ð, 1 우, 11024, Aug. 10, 1954, K. Koba leg. ; Yakkachi-gawa (Shinmura), 8 ๙, 3 우, young crabs-laden 3 우, m. 1029, Oct. 17, 1968, H. Minei leg.

Fukumoto, Yamato-son, 1 \% , 10932, Jul. 31, 1964, K. Koba \& K. Baba leg.

Tokuno-shima. Tete, Tokunoshima-cho, $1 \succsim, \mathrm{m}$. 1074, Mar. 29, 1970, H. Minei leg. ; Ketokina, 1 ๙, 1 우, m. 1070, Mar. 28, 1970, H. Minei leg. ; Inokawa, 1 , m. 1065, Mar. 27, 1970, H. Minei leg.

Masena-gawa (Minata), Amagi-cho, 1 우, young crabs-laden 1 우, m. 1082, Oct. 8, 1968, H. Minei leg. ; Akirigami-gawa (Ishikiridome), $2 \precsim, \mathbf{3}$, young crabsladen 2 f, m. 1086a, Oct. 9, 1968, H. Minei leg.

Shikaura-gawa (Bane), Isen-cho, $3 \curvearrowright, 2$ ㅇ, m. 1084, Oct. 10, 1968, H. Minci leg. ; 1 우, m. 1067, Mar. 26, 1970, H. Minei leg.

Material illustrated. Dorsal view of male and first pleopod ; Holotype. Dorsal view of female; Akirigami-gawa, young crabs-laden 1 \&, m. 1086a, Oct. 9, 1968, H. Minei leg.

Diagnosis. Carapace rather quadrate; postorbital region with short striae ; epibranchial tooth distinct ; subbranchial region not distended laterally. Chelipeds subequal in both sexes: second ambulatory leg 1.8 times the breadth of carapace, seventh abdominal segment longer than the 6th. Penultimate segment of first pleopod slightly curved inwards, broad proximally and depressed ventrally; ultimate segment slender, triangular and slightly curved outwards ; synovial membrane slender, 5.0 times as long as broad.

Description of holofype. The length of the carapace is fully $7 / 8$ times its greatest breadth and the depth is slightly more than half the length. The dorsal surface behind the postfrontal region is moderately convex in a fore and aft direction and nearly flat from side to side. The postfrontal region is distinct, bears five smooth, short, transverse rugae. The median groove is distinct and the postfrontal region is readily distinguished from the postorbital region by the short lateral groove. The postorbital region bears ten smooth, short transverse rugae, and is distinguished from the epibranchial region by the short groove. The inflated portions of the branchial regions bear large, smooth, tubercles. The epibranchial tooth is small but distinct. The anterolateral margin is faintly arched, finely crenulate, shorter than the posterolateral margin and about as long as the posterior margin. The posterolateral and subbranchial regions bear many fine crenulate striae. The subbranchial region is not inflated.

The frontal region is moderately declivous, and one-third as broad as the carapace; its margin is faintly bilobed, slightly crenulate, and bears above large smooth tubercles. The orbital margin is composed of rounded crenulate striae. The upper parts of the pterygostomian and subhepatic regions bear indistinctly granulate and short striae; the lowerpartsare smooth. The exopod of the third maxilliped reaches the proximal fourth of the merus ; the merus is as long as broad.

The 6th abdominal segment is 0.47 times as long as broad and slightly shorter than the 

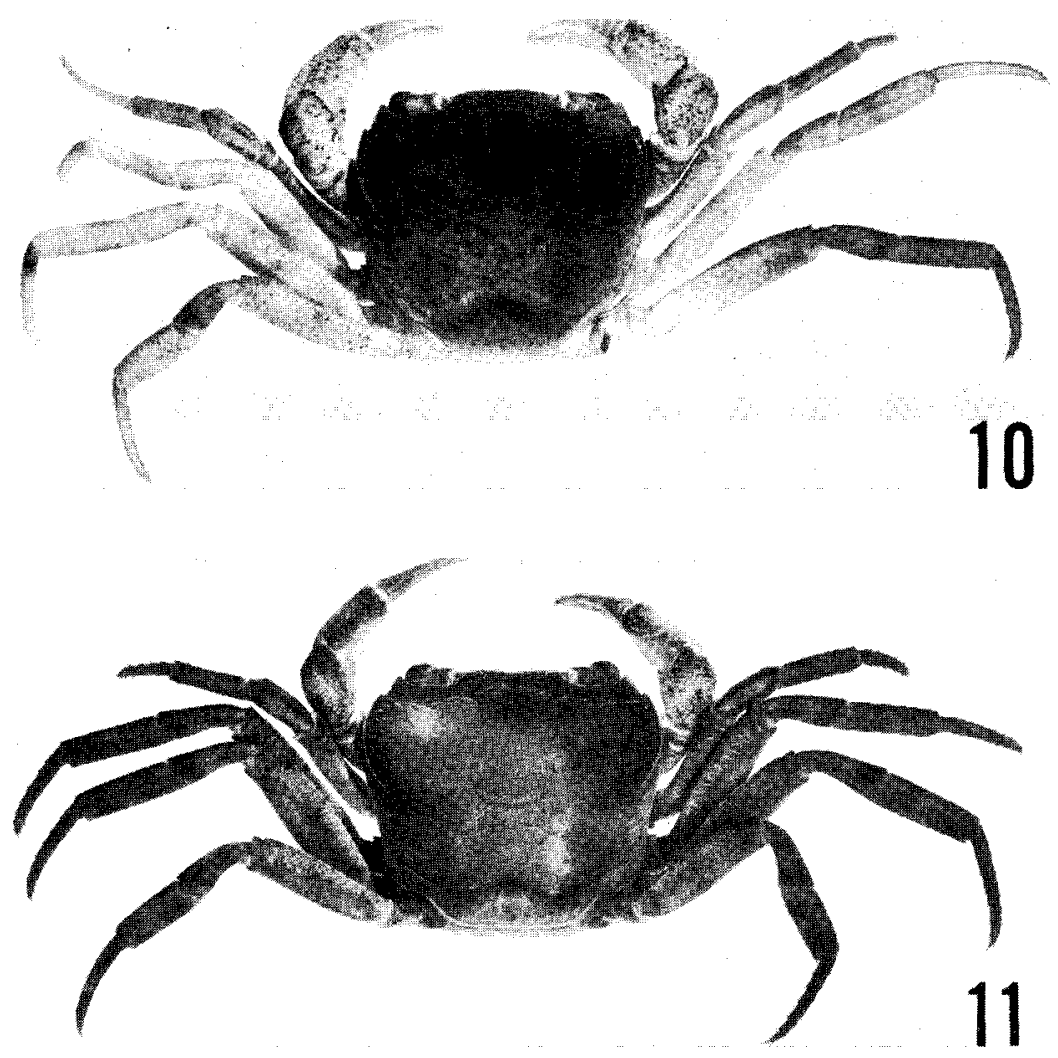

Figs. 10-11. Candidiopotamon amamense sp. nov. 10 : Holotype. 11 : female.

7th. The 7 th segment is 0.63 times as long as broad. The first pleopod is stout ; its length is 2.9 times the greatest breadth; the penultimate segment is 4.1 times as long as the ultimate ; slightly curved inwards ; it is broad proximally and depressed ventrally. The ultimate segment is slender, triangular and slightly curved outwards; the synovial membrane is slender, being 5.0 times as long as broad.

The chelipeds are similar and subequal, but the left is slightly longer than the right. The merus bears short rugae. The dorsal surface of the carpus bears rugae and one large spine and two spinules on the inner margin. The palm is smooth on the inner surface and has indistinct rugae and granules on the outer surface. The upper margin of the palm is slightly longer than broad, and are 0.65 times as long as the dactylus. The fingers are slender, bear 22 to 26 small teeth ; they are do not gaped when closed. The dactylus is 0.56 times as long as the chela. The ambulatory legs are slender, with short hairs. The 2 nd ambulatory leg is 1.84 times the breadth of the carapace; the propodus is 3.0 times as long as broad, and bears a longitudinal row of spinules medially. The propodus and the dactylus bear each two rows of spinules dorsally and ventrally. Seventeen spinules are present on the ventral margin of the dactylus.

Remarks. This species is allied to Candidiopotamon rathbuni (de Man) from Taiwan. I have compared it with the material of $\mathrm{C}$. rathbuni collected from 
Taiwan and found that it differs in the conspicuous features enumerated below:

1. The postorbital region has several smooth, short rugae.

2. The 2nd ambulatory leg is 1.84 times the breadth of the carapace: the propodus is 3.0 times as long as broad,

3. The 7th abdominal segment is slightly longer than the 6 th. The ultimate segment of the first pleopod is slender, triangular and slightly curved outwards ; the synovial membrane is 5.0 times as long as broad.

Measurements. See Table 2.

Distribution. Amami-ohshima, Tokuno-shima.

\section{Candidiopotamon okinawense sp. nov.}

(Figs. 12; 15 C, D )

New Jap. name : Okinawa-minami-sawagani

Material examined. Holotype. Fuku-gawa (branch of Aha-gawa), Kunigamison, Okinawa-jima, $\lesssim, Z L K U m .1104$, Jul. 2, 1972, T. Tomori, R. Kochi \& H. Minei leg.

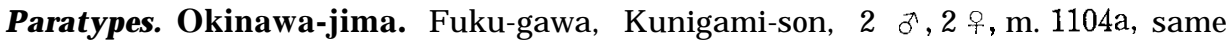
data as holotype ; Yonaha-dake, 2 우, m. 1004, May 21, 1961, H. Minei leg. ; Yonagawa, 3 ๙, 3 ㅇ, m. 1003, Jul. 10, 1962, H. Minei leg.

Takazato, Ohgimi-son, 7 a, 1 오, m. 1002, May 22, 1961, H. Minei leg.

Genga-gawa, Nago city, 1 §, 1 ㅇ, m. 1001, Feb. 26, 1962, K. Kawashima leg. ; $2 \precsim, 2$ 우, m. 1105, Jun. 29, 1972, Y. Nakasone \& H. Minei leg.

Material illustrated. Holotype.

Diagnosis. Postorbital region with one long and three short striae ; exopod of third maxilliped failing to reach the proximal third of merus. Propodus of 2nd ambulatory leg with two rows of spinules dorsally. First pleopod stout ; ultimate segment slightly curved inwards; penultimate segment 3.3 times as long as ultimate ; synovial membrane 1.6 times as long as broad.

Description of holotype. The carapace is quadrangular and practically flat excluding the frontal and orbital regions. The length of the carapace is 0.89 times its greatest breadth and the depth is half the length of the carapace. The postfrontal region bears some tubercles and crenulate striae. The postorbital region bears one long and three short transverse striae. The epibranchial region has some smooth tubercles and crenulate striae. The epibranchial tooth is distinct. The anterolateral margin of the carapace is roundly crenulate and its posterior margin ends slightly inwards to the dorsum of the carapace. The posterolateral margin and the subbranchial region bear many granulated striae. The frontal region is 0.33 times the breadth of the carapace, and 0.39 times the distance between the external orbital teeth. The orbital region is narrow, smooth and its margin is crenulate. The subhepatic and suborbital regions are crenulate and have granulated striae. The pterygostomian region is crenulate on the upper part, but smooth on the lower. The exopod of the third maxilliped reaches the proximal fourth of the merus ; the merus is as long as broad.

The 6 th abdominal segment is 0.55 times as long as broad, and slightly longer than the 7th segment. The 7th segment is 0.62 times as long as broad. The first pleopod is stout ; 
Table 2. Measurements of four species (in $\mathrm{mm}$ ).

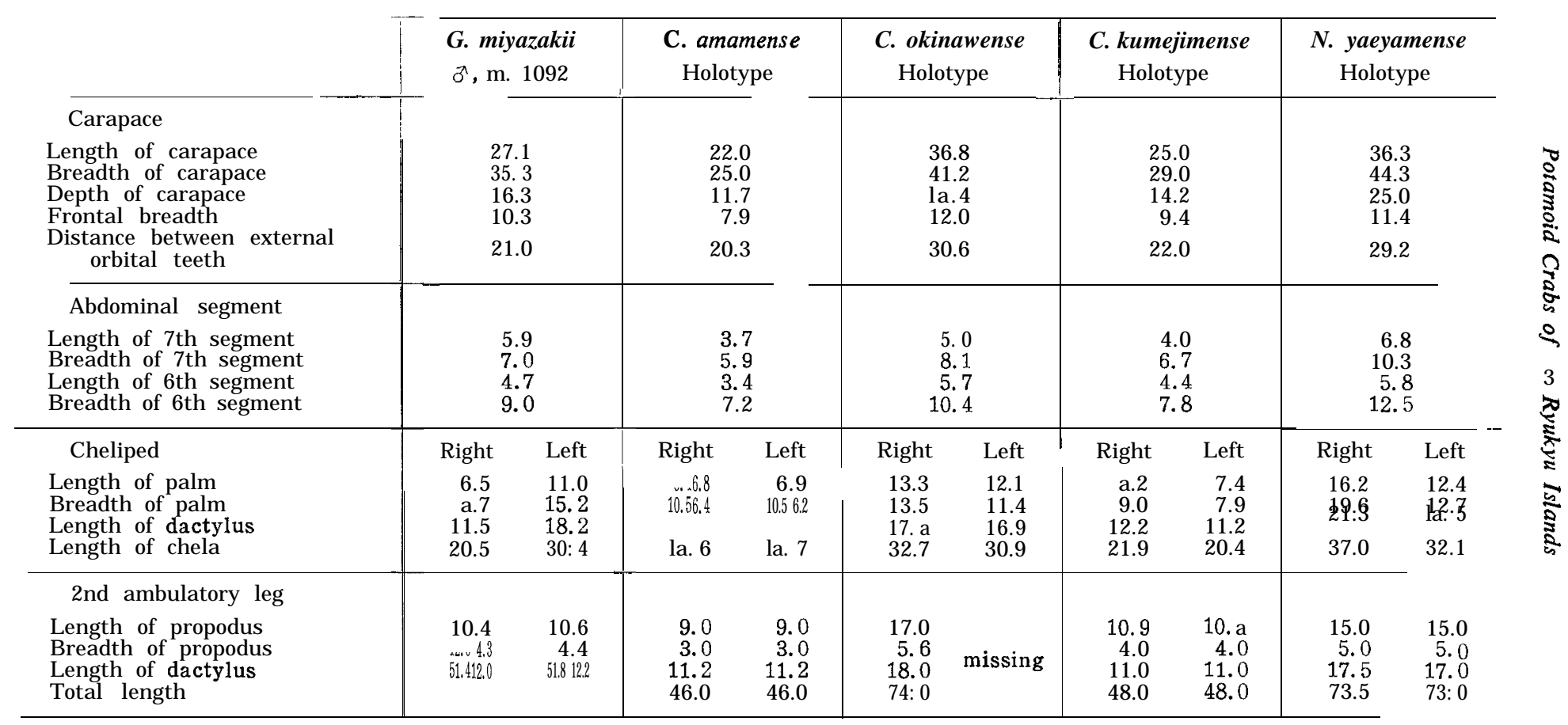


the ultimate segment is slightly curved inwards; the penultimate segment is 3.3 times the length of the ultimate; the synovial membrane is 1.6 times as long as broad.

The chelipeds are similar and subequal, but the right is slightly longer than the left. The carpus is distributed by crenulate striae, and has one large spine and one spinule internally. The upper surface of the palm bears many granulate striae, but is sparsely granulate on the lower. The palm is slightly shorter than broad, and 0.75 times the length of the dactylus. The fingers are not gaping, with a series of many small teeth on the cutting edges. The ambulatory legs are slender, with short hairs. The 2 nd ambulatory leg is 1.8 times the breadth of the carapace; the propodus is 3.0 times as long as broad, and bears a longitudinal row of spinules medially. The propodus and the dactylus bear each two rows of spinules dorsally and ventrally. Twelve spinules are present on the ventral margin of the dactylus.

Remarks. This species is very close to Candidiopotamon rathbuni (de Man) in general appearance, but it differs in the following. In C. rathbuni the orbital region is wide, the subbranchial region is moderately swollen. The ultimate segment of the first pleopod is moderately curved inwards. The propodus of the 2nd ambulatory leg is 2.5 times as long as broad, On the other hand, in C. okinawense the orbital region is narrow, the subbranchial region is not swollen. The ultimate segment of the first pleopod is slightly curved inwards. The propodus of the 2nd ambulatory leg is $\mathbf{3 . 0}$ times as long as broad.

Measurements. See Table 2.

Distribution. Okinawa-jima.

\section{Candidiopotamon kumejimense sp. nov.}

(Figs. 13; $15 \mathrm{E}, \mathrm{F})$

New Jap. name : Kumejima-minami-sawagani

Material examined. Holotype. Hiyazo, Nakazato-son, Kume-jima, ð,ZLKUm. 1107, Jan. 26, 1972, Y. Aramoto leg.

Paratypes. Kume-jima. Hiyazo, $2 \AA, 2$ 우 m. 1107a, same data as holotype; Zanado, 1 ๙ , m. 1008, Aug. 22, 1960, K. Yamazato \& H. Minei leg.

Nakachi, Gushikawa-son, 1 ๙, 9663, Aug. 26, 1960, K. Yamazato \& H. Minei leg.

Material illustrated. Holotype.

Diagnosis. Postorbital region with two long and one short striae ; exopod of third maxilliped reaches proximal third of merus. Propodus of 2nd ambulatory leg with one row of spinules dorsally. First pleopod stout; penultimate segment 3.8 times as long as ultimate ; ultimate segment straight ; synovial membrane 1.8 times as long as broad.

Description of holotype. The carapace is quadrangular and distinctly flattened excluding the frontal and the orbital regions. The length of the carapace is 0.86 times its greatest breadth and the depth is slightly more than the length of the carapace. The postfrontal region bears crenulate, short striae. The postorbital region has two long and one short transverse striae. The epibranchial region bears some smooth tubercles and short striae. The anterolateral margin of the carapace is crenulate and its posterior margin ends slightly inwards 


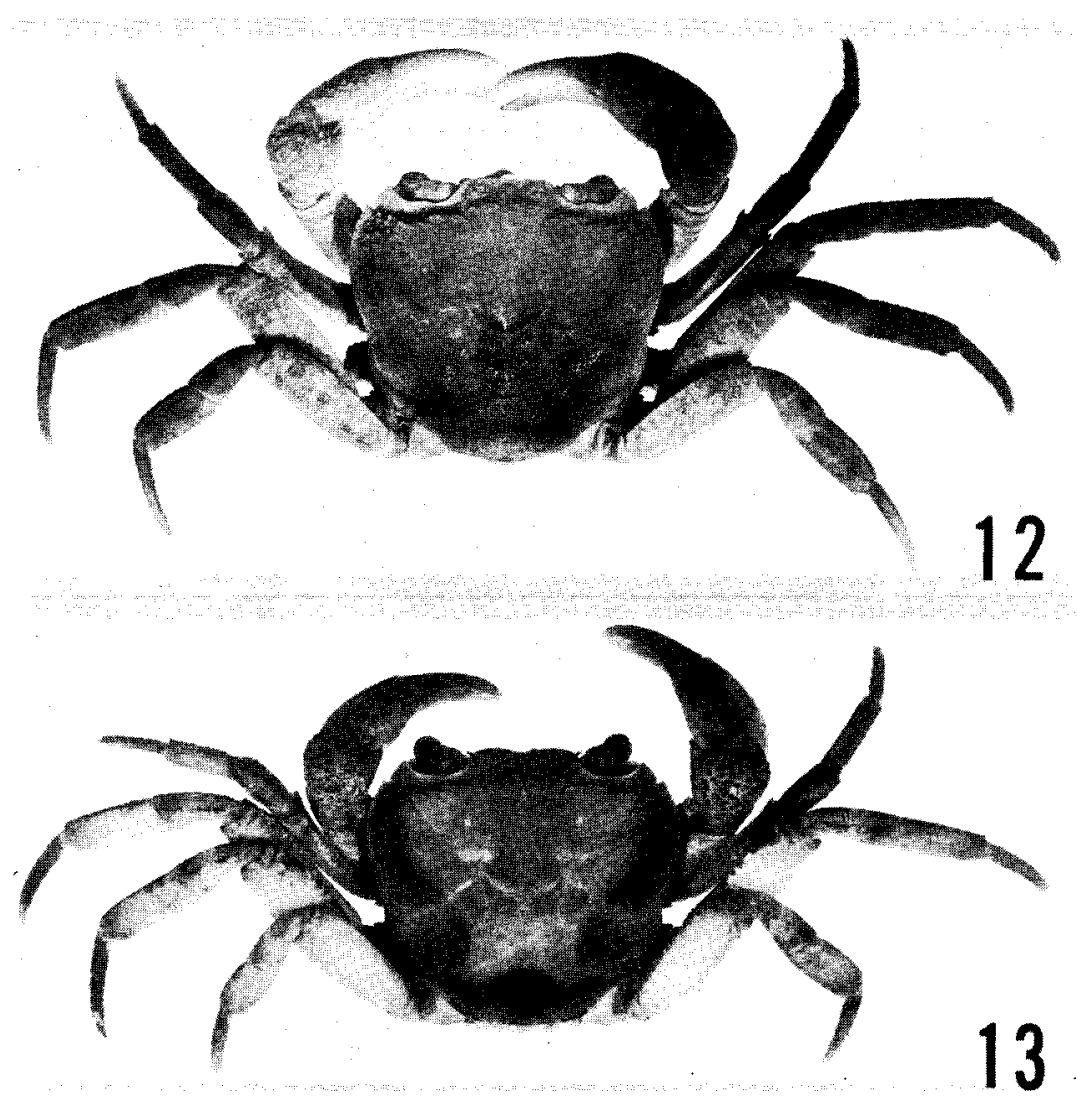

Figs. 12-13. 12 : Candidiopotamon okinawense sp. nov. 13 : Candidiopotamon kumejimense sp. nov.

to the dorsum of the carapace. The posterolateral margin and the subbranchial region bear many short striae. The frontal region bears many tubercles, it is 0.33 times as broad as the carapace, and 0.43 times the distance between the external orbital teeth. The orbital region is narrow and is distinctly crenulate on the margin. Between the suborbital and the subhepatic regions have short striae. The pterygostomian region bears many short striae on the upper part and is smooth on the lower part. The exopod of the third maxilliped reaches the proximal third of the merus ; the propodus is slightly longer than broad.

The 6th abdominal segment is 0.56 times as long as broad, and slightly longer than the 7 th; the 7 th segment is 0.60 times as long as broad. The first pleopod is stout ; the penultimate segment is 3.8 times the length of the ultimate; the ultimate segment is straight; the synovial membrane is 1.8 times as long as broad.

The chelipeds are similar and subequal, but the right is slightly longer than the left. The palm bears many crenulate short striae. In the right cheliped the palm is 0.91 times as long as broad and 0.67 times the length of the dactylus. The fingers are slender, not gaping with a series of many small teeth on the cutting edges. The ambulatory legs are slender and have sparsely short hairs on the dactylus and the propodus. The 2nd ambulatory leg is 1.7 times the breadth of the carapace; the propodus bears 2.7 times as long as broad. The propodus bears one row of spinules dorsally and two rows of spinules ventrally ; the dac- 
tylus bears each two rows of spinules ventrally and dorsally. Ten spinules are present on the ventral margin of the dactylus.

Remarks. This species is very allied to Candidiopotamon okinawense, from which it is easily distinguished by the following characters. In C. okinawense the body is large in size and the ultimate segment of the first pleopod is slightly curved inwards, and the postorbital region bears one long and three short striae, while the present species is of small size and the ultimate segment is straight, and the postorbital region bears two long and one short striae. In C. okinawense the propodus of the 2nd ambulatory leg bears two rows of spinules dorsally, however, in the present species the propodus bears a single row of spinules.

Measurements. See Table 2.

Distribution. Kume- jima.

Nanhaipotamon globosum (Parisi, 1916)

Jap. name : Menaga-yamagani

Potamon (G eothel phusa) globosum Parisi 1916, p. 164, pl. 5, figs. 1, 2.

G eothelphusa gl obosa : Balss 1937, p. 167, fig. 31.

Potamon globosum : Pretzmann 1963, p. 367, pl. 4, fig. 14.

Isolapotamon (Nanhaipotamon) formosanum globosum : Bott 1968, в. 125, fig. 10

Nanhaipotamon formosanum globosum : Bott 1970, p. 196, pl. 41, fig. 84 ; pl. 57, fig. 84.

Material examined. None.

Distribution. Okinawa-jima(Parisi 1916 ; Balss 1937 ; Pretzmann 1963 ; Bott 1968, 1970).

Nanhaipotamon yaeyamense sp. nov.

(Figs. 14; $15 \mathrm{G}, \mathrm{H}$ )

New Jap. name : Yaeyama-yamagani

Material examined. Holotype. Omoto-dake, Ishigaki city, Ishigaki-jima, $\sigma^{\star}$, ZLKU 13744, Sept. 5, 1969, T. Tamaki leg.

Paratypes. Ishigaki-jima. Omoto-dake, Ishigaki city, 1 §, ZLKUm. 1115, same data as holotype ; Todoroki-gawa, 2 ð, m. 1006, Jun. 14, 1963, S. Kudaka leg. ; Pensan-gara, 1 ð, 5 우, m. 1007, May 19, 1963, S. Kudaka leg.

Iriomote-jima. Komi, Taketomi-cho, 1 ð, m. 1116, Mar. 7, 1959, H. Minei leg. ; Ohhara, 1 a, m. 1114, Dec. 15, 1965, T. A. Uchida leg.

Material illustrated. Holotype.

Diagnosis. Carapace oval, strongly convex dorsally. Epibranchial tooth distinct. Gape of cheliped small. Sixth abdominal segment shorter than 7th. First pleopod moderately curved outwards ; ultimate segment strongly curved outwards and not distensible; synovial membrane 1.6 times as long as broad.

Description of holotype. The carapace is oval and strongly convex in a fore and aft direction. The length of the carapace is 0.82 times its greatest breadth, and the depth is 0.69 times the length of the carapace. The postfrontal and postorbital regions bear short 


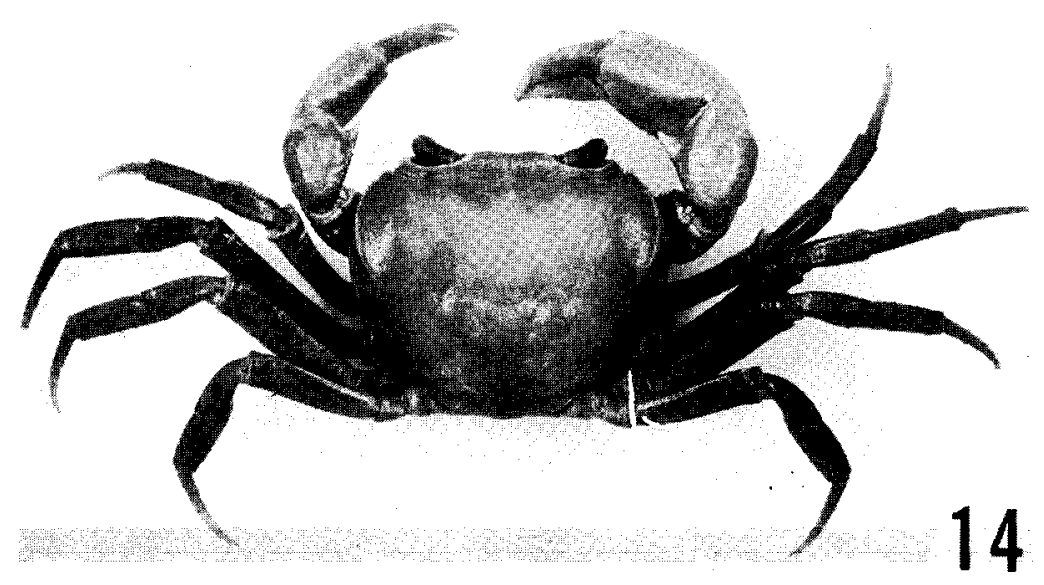

Fig. 14. Nanhaipotamon yaeyamense sp. nov.

striae. The epibranchial region is indistinctly crenulate ; the epibranchial tooth is distinct. The anterolateral margin of the carapace bears indistinct crenulate striae and its posterior end turns little inwards on the dorsum of the carapace. The posterolateral margin of the carapace bears some fine striae, but the subbranchial region bears many fine short striae. The front is strongly declivous, and is indistinctly crenulate ; it is 0.26 times the breadth of the carapace, and 0.39 times the distance between the external orbital teeth. The suborbital region is smooth on the upper part, but crenulate on the lower. The pterygostomian region is crenulate on the upper, but smooth on the lower. In the third maxilliped the exopod reaches the proximal fourth of the merus; the merus is as long as broad.

The 6th abdominal segment is 0.46 times as long as broad and shorter than the 7th; the 7th segment is 0.66 times as long as broad. The first pleopod is moderately curved outwards ; the penultimate segment is 7.0 times the length of the ultimate; the ultimate segment is strongly curved outwards and not distensible; the synovial membrane is 1.6 times as long as broad.

The chelipeds are unequal, the right one being moderately longer than the left. In the right cheliped the palm bears indistinctly short striae; it is 0.83 times as long as broad and 0.76 times the length of the dactylus. The dactylus is 0.58 times the length of the chela. The fingers have a small gape, with a series of indistinctly small teeth on the cutting edge. The ambulatory legs are slender, with short hairs on the propodus and the dactylus. The 2nd ambulatory leg is 1.7 times the breadth of the carapace ; the propodus bears a row of spinules dorsally and two similar rows ventrally; it is 3.0 times as long as broad. The dactylus bears each two rows of the spinules dorsally and ventrally; the ventral two rows are composed of 8 spinules.

Remarks. This species is very allied to Nanhaipotamon globosum (Parisi) and Nanhaipotamon formosanum (Parisi) in chelipeds and the first pleopod, but it is distinguished from them by the following respects. (1) In N. globosum and N. formosanum the fingers are largely gaping, whereas in $\mathrm{N}$. yaeyamense the gaping is weak. (2) In N. globosum and N. formosanum the first pleopod is stout and straight, its ultimate segment being distended inside near the middle. However, in $N$. yaeyamense the first pleopod is slender and curved outwards, the ultimate segment being strongly curved outwards. 


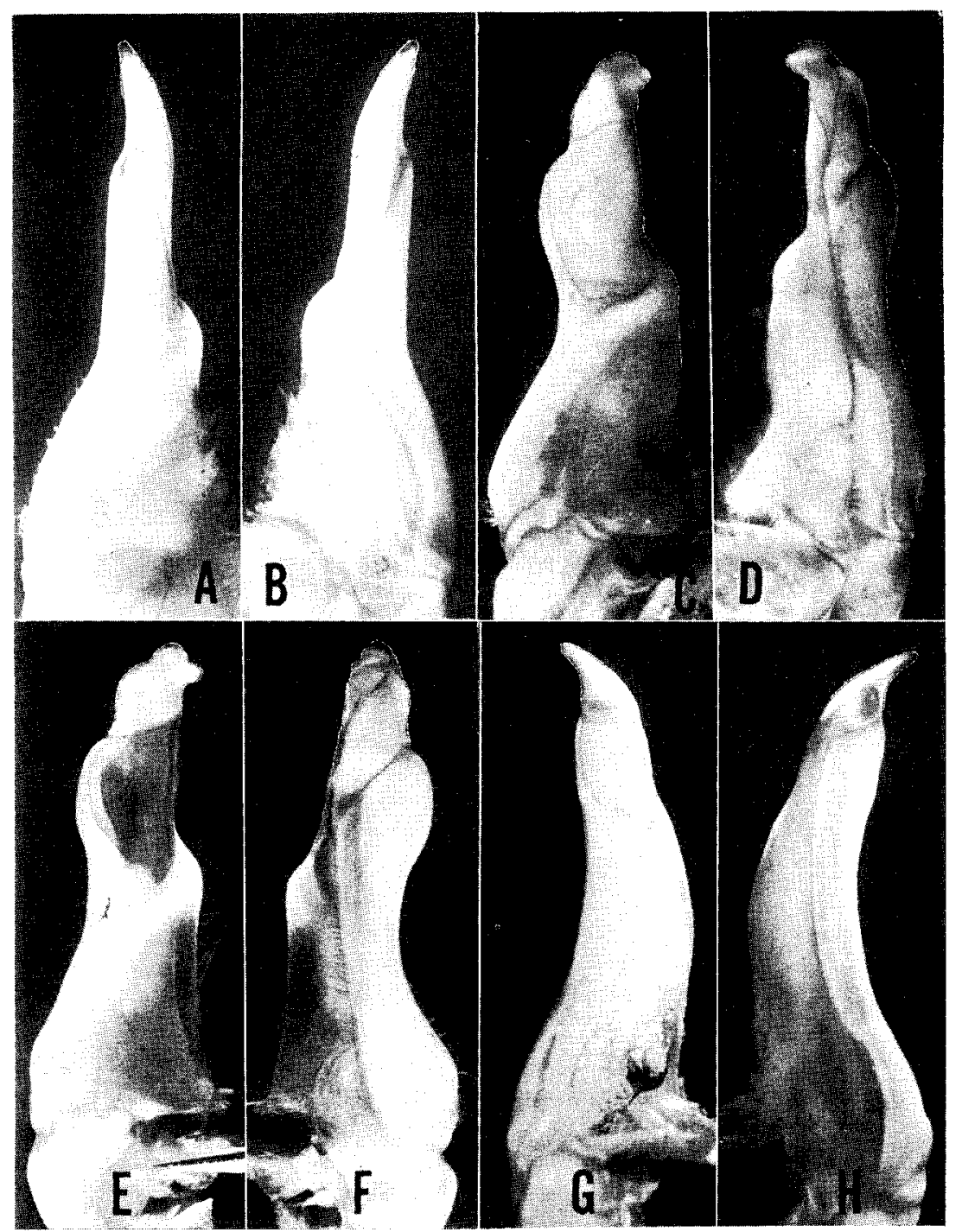

Fig. 15. Left first pleopod of four new species. A, B: Candidiopotamon amamense sp. nov. C, D : Candidiopotamon okinawense sp. nov. E, F : Candidiopotamon kumejimense sp. nov. G, H : Nanhaipotamon yaeyamense sp. nov.

Measurements. See Table 2.

Distribution. Ishigaki-jima, Iriomote-jima.

\section{ACKNOWLEDGEMENTS}

I am greatly indebted to thank Professor Emeritus Sadayoshi Miyake of the Kyushu University for many valuable suggestions rendered during the course of thiswork. Thanks are also due to Prof. Kazuo Koba and Dr. Keiji Babao f 
the Kumamoto University; Prof. Teru Aki Uchida and Prof. KenjirôKawashima of the Kyushu University ; Dr. Masatsune Takeda of the Nihon University ; Dr. Yoshihisa Hashiguchi of the Kochi University; Prof. Kiyoshi Yamazato, Dr. Yukio Nakasone, Mr. Shigemitsu Shokita and Mr. Toshio Tamaki of the Ryukyu University: Mr. Seiki Kudaka of the Futenma High School; Mr. Ryojin Kochi of the Hokuzan High School; Mr. Tetsuo Tomori of the Nago High School; Mr. Yoin Aramoto of the Okinawa Education Center for providing me with the materials.

\section{REFERENCES}

Alcock, A. 1910 Catalogue of the Indian Decapod Crustacea in the collection of the Indian Museum. Part I. Brachyura Fasc. II. The Indian Fresh-water crabs. Potamonidae. Calcutta., pp. 1-130

- 1910a On the classification of the Potamonidae (Telphusidae). Rec. Znd. Mus., 5: 253-263

Balss, H. 1937 Potamoniden (Dekapoda, Brachyura) der Philippinen und des Malayischen Archipels. Int. Rev. d. ges. Hydr. u. Hydr., 34 : 143-187

Bott, R. 1967 Potamiden aus Ost-Asien. Senckenbergiana biol., 48 : 203-220

— 1968 Potamiden aus Süd-Asien(Crustacea, Decapoda). Ibid., 49 : 119-130

- 1970 Die Süßwasserkrabben von Europa, Asien, Australien und ihre Stammesgeschichte. (Crustacea, Decapoda). Abh. Senckenb. Naturforsch. Ges., $526: l-338$

Haan, de, W. 1835 Crustacea, in : de Siebold, Fauna Japonica, p. 52

Holthuis, L. B. and T. Sakai 3970 Ph. F. Von Siebold and Fauna Japonica. A History of early Japanese Zoology. Academic Press of Japan, Tokyo, p. 127.

Koba, K. 1936 Studies on the Japanese Potamonidae (1). Notes on Potamon rathbuni de Man, as a second intermediate host of Paragonimus westermani (Kerbert) in Formosa. Trans. Nat. Hist. Soc. Formosa, 26: 164-174 (In Japanese)

Maki, M. and H. Tsuchiya 1923 Decapod Crustacea from Formosa. Report of the Agricultural Department, the Central Institution of the Government-General of Taiwan, Taipei, Formosa, no. 3, pp. 153-155 (In Japanese)

Man, de, J. G. 1892 Decapoden des Indischen Archipels. In "Max Weber: Zoologische Ergebn. Einer Reise in Niederl, $2: 290$

- 1914 Note sur quelques crustacés décapodes brachyures terrestres et d'eau douce appartenant au Musée Civique de Genes. Ann. Mus. Civ. Stor. Nat., 6 : 122-138

Miers, E. J. 3886 Report on the Brachyura collected by H. M. S. Challenger during the years 1873-1876. Report Voy. Challenger. XVII, pt. II, p. 215.

Milne Edwards, A. 1869 Revision du Genre Thelphuse et description de quelques espèces nouvelles, faisant partie de la collection de Museum. Nour. Arch. Mus. Hist. Nat., 5 : 175

Minei, H. 1963 On the habitat and ovigerous habit of the female a freshwater crab, Potamon (Geothelphusa) sakamotoana Rathbun from Okinawa-jima Island, the Ryukyu Islands. Sci. Bull. Fac. Agric. Kyushu Univ., 20 : 365-372 (In Japanese with English summary) 1968 Fresh-water crabs of Japan. Nature Study., 14 : 94-99 (In Japanese)

Miyake, S. 1963 On Decapod Crustaceans from the Yaéyama Group, Ryukyu Islands. Reports of the Committee on Foreign Scientific Reseach, Kyushu University, no. 1, p. 66 (In Japanese)

— and J. K. Chiu 1965 A new potamonid crab, Potamon (Geothelphusa) miyazakii sp. nov., as an intermediate host of the lung-fluke from Formosa. J. Fac. Agric. Kyushu Univ., 13: 595400

— and H. Minei 1965 A new fresh-water crab, Potamon (Geothelphusa) tenuimanus sp. nov., from Okinawa-jima, the Ryukyu Islands. Sci. Bull. Fac. Agric. Kyushu Univ., 21 : 
377-382 (In Japanese with English summary)

Ortmann, A. 1897 Carcinologische Studien. Zool.Jahrb.Syst., 10 : 310

Parisi, B. 1916 I Decapodi giapponesi del Museo di Milano. IV. Cyclometopa. Atti della Soc.

Ital. Nat., $55: 153-170$

Pretzmann, G. 1963 U̇ber einige Süd- und Ostasiatische Potamoniden. Ann. Nuturhistor, Mus., 66 : 367

Rathbun, M. J. 1898 Descriptions of three new species of fresh-water crabs of genus Potamon. Proc. Biol. Soc., 12: 27-30

1905 Les crabes d'eau douce. Nouv. Arch. Mus. His Nat., 6 : 225-312

Sakai, T. 1939 Studies on the crabs of Japan. IV. Brachygnatha, Brachyrhyncha. Yokendo, Tokyo, p. 580.

1965. The crabs of Sagami Bay. Maruzen, Tokyo, p. 174.

Stimpson, W. 1858 Prodromus descriptionis animalium everatorum, . . , pars 7, Crustacea Ocypodidea. Proc. Acad. Nat. Sci., 10: 101

1907 Report on the Crustacea (Brachyura and Anomura) collected by the North Pacific Exploring Expedition 1853-1856. Smiths. Inst. M isc. Coll. Washington, 49 :112-113

White, A. 1847 List of the speimens of Crustacea in the collection of the British Museum, p. 30 